This is the final draft post-refereeing.

The publisher's version can be found at

https://www.sciencedirect.com/science/article/pii/S0268005X20315253

Please cite this article as: Monge-Morera, M. Lambrecht, M.A., Deleu, L.J., Godefroidt, T., Goos, P.,Rousseau, F., Schymkowitz, J. and Delcour, J.A. Drying mode and hydrothermal treatment conditions govern the formation of amyloid-like protein fibrils in solutions of dried hen egg white, Food Hydrocolloids, 112, 106276.

\title{
Drying mode and hydrothermal treatment conditions govern the formation of amyloid-like protein fibrils in solutions of dried hen egg white
}

\author{
Margarita Monge-Morera ${ }^{1 *}$, Marlies A. Lambrecht ${ }^{1}$, Lomme J. Deleu ${ }^{1}$, Thibault Godefroidt ${ }^{1}$, \\ Peter Goos ${ }^{2}$, Frederic Rousseau ${ }^{3}$, Joost Schymkowitz ${ }^{3}$, Jan A. Delcour ${ }^{1}$
}

${ }^{1} \mathrm{KU}$ Leuven, Laboratory of Food Chemistry and Biochemistry and Leuven Food Science and Nutrition Research Centre (LFoRCe), Kasteelpark Arenberg 20, B-3001 Leuven, Belgium

${ }^{2}$ Division of Mechatronics, Biostatistics and Sensors (MeBioS), KU Leuven, Kasteelpark Arenberg 30,

$$
\text { B-3001 Leuven, Belgium }
$$

${ }^{3} \mathrm{KU}$ Leuven, Switch laboratory, Department of Cellular and Molecular Medicine, Herestraat 49, B3001 Leuven, Belgium

*Corresponding author, Tel.: +32 16 329082; fax: +32 16321997

E-mail address: margarita.mongemorera@kuleuven.be

\section{Abstract}

2 The recipe of some food products contains dried hen egg white (EW). It is convenient in use and available with a range of functionalities as a result of being stored under different time, temperature and moisture conditions following drying. Amyloid fibrils are fibrillary protein structures composed of highly ordered stacking of cross- $\beta$ sheets. They can contribute to the foaming and gelling capacity of EW proteins. We here for the first time report that dried EW contains amyloid-like fibrils and that such fibrils in spray-dried EW (EW $\mathrm{SD}_{\mathrm{SD}}$ ) are longer (ca. 100 to $200 \mathrm{~nm}$ ) than those in freeze-dried EW [EW $\mathrm{FD}$ ] (ca. 20 to $100 \mathrm{~nm}$ ). In addition, conditions for optimal fibrillation were determined for both $\mathrm{EW}_{\mathrm{FD}}$ and freeze-dried ovalbumin (OVA $A_{F D}$ ) using a response surface design. Dilute solutions of $O V A_{F D}$ and $E W_{F D}$ were incubated at different $\mathrm{pH}$ values, times and temperatures. After storage at optimal conditions $\mathrm{OVA}_{\mathrm{FD}}\left[2.0 \%\left(\mathrm{w}_{\text {protein }} / \mathrm{v}\right), \mathrm{pH} 7.0,23 \mathrm{~h}, 76^{\circ} \mathrm{C}\right]$ and $\mathrm{EW}_{\mathrm{FD}}\left[0.5 \%\left(\mathrm{w}_{\text {protein }} / \mathrm{v}\right), \mathrm{pH} 7.0,24 \mathrm{~h}, 85^{\circ} \mathrm{C}\right]$, a higher 
level of cross- $\beta$ sheet structures and larger worm-like protein fibrils were observed for OVA $A_{F D}$ than for $\mathrm{EW}_{\mathrm{FD}}$. Lastly, when EWSD stored for one week at either $50{ }^{\circ} \mathrm{C}$ and $50 \%$ relative humidity $(\mathrm{RH})$

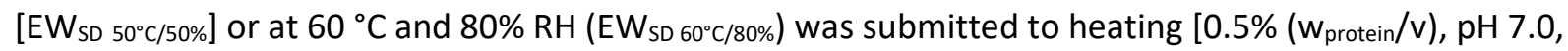
$24 \mathrm{~h}, 85^{\circ} \mathrm{C}$ ], a higher extent of fibrillation was found for $\mathrm{EW}_{\mathrm{SD} 60^{\circ} \mathrm{C} / 80 \%}$ than for $\mathrm{EW}_{\mathrm{SD}} 50^{\circ} \mathrm{C} / 50 \%$. Thus, drying induces EW amyloid-like protein fibrillation. Also dry heating $\mathrm{EW}_{\mathrm{SD}}$ at $60{ }^{\circ} \mathrm{C}$ and $80 \% \mathrm{RH}$ further enhances such fibrillation during heating in excess of water.

Keywords: spray-dried, freeze-dried, dry heating, thioflavin T, ovalbumin.

\section{Introduction}

Hen (Gallus gallus domesticus) egg white (EW) is commonly used in a variety of foods (e.g. baking and meat products) due to the excellent gelling and foaming capacity of its proteins [protein content ca. $83 \%$ of dry matter (dm)] (Mine, 2002; Powrie \& Nakai, 1985). Dried EW products have high shelf life, are easy to handle and have specific functional properties (Mine, 1995).

EW powders can be produced by freeze-drying. In this method, ice sublimation occurs under low pressure. It generally results in less thermal and evaporation stress on proteins than spray-drying (Haque \& Roos, 2006; Liapis \& Bruttini, 2007). However, freeze-drying itself can also alter the functionality of EW. For instance, the foaming capacity of rehydrated freeze-dried EW is lower than that of rehydrated spray-dried EW (Chen et al., 2012; Lili et al., 2015).

Spray-drying is the most popular industrial drying technique for producing EW powders. In this method, fresh EW is atomized at air inlet temperatures exceeding $160{ }^{\circ} \mathrm{C}$ (Ma et al., 2013; Sosnik \& Seremeta, 2015). Protein denaturation is limited during spray-drying because of the short processing times (5 to 30 s) (Sosnik \& Seremeta, 2015). However, the increase in surface area and the exposure to temperatures exceeding $60{ }^{\circ} \mathrm{C}$ during spray-drying can result in (partial) protein thermal denaturation and aggregation. As a result, the gelling and foaming capacity of EW is modified (Chen et al., 2012; Lechevalier et al., 2007).

Spray-dried EW powders are often stored at elevated temperatures $\left(>60^{\circ} \mathrm{C}\right)$ and humid conditions for multiple days ( 3 to 30 days). Such storage is commonly referred to as dry heating. It enhances the gelling and foaming properties of solubilized EW powders containing $c a .10 \%\left(w_{\text {protein }} / v\right)$ by inducing structural changes in the protein (Baron et al., 2003; Mine, 1996, 1997). For example, storage at $75^{\circ} \mathrm{C}$ for 15 days of dried EW (8.5\% moisture content) at mild alkaline $\mathrm{pH}$ ( $\mathrm{pH}$ about 9.5) greatly improves its gelling properties when re-dissolved to contain $c a .10 \%\left(w_{\text {protein }} / v\right)$. This improvement has been ascribed to the formation of specific protein aggregates (Mine, 1997). Under similar storage conditions 
but at higher $\mathrm{pH}(\mathrm{pH}>9.5)$, different protein aggregates are formed which then results in lower gelling properties in similar dispersions. During both treatments, protein surface hydrophobicity increases and sulfhydryl-disulfide exchange reactions occur. However, at $\mathrm{pH}>9.5$ some covalent bonds are formed which render the protein aggregates insoluble (Mine, 1997). Maillard reactions can also improve dried EW protein functionality and in particular its gelling properties (Ma, Zhao, \& Chi, 2019). Apparently, advanced glycation end-products formed during Maillard reaction can promote amyloidosis (Zhang et al., 2009). For instance, glycation of lysozyme with glycol aldehyde has resulted in amyloid-like aggregates (Mariño et al., 2017).

To the best of our knowledge, studies on the type of protein aggregates (e.g. globular or fibrillary) formed during storage of dried EW under a range of temperature, time and relative humidity $(\mathrm{RH})$ conditions are limited. However, storage of ovalbumin (OVA) powder, the most abundant EW protein (ca. $54 \%$ ), at $75{ }^{\circ} \mathrm{C}$ and $65 \% \mathrm{RH}$ for up to 15 days produces small (ca. 1 to $100 \mathrm{~nm}$ ) protein aggregates when re-dissolved to contain $c a .1 \%\left(w_{\text {protein }} / v\right)$, which are stabilized by intermolecular cross-linkages (e.g. disulfide bonds) and hydrophobic interactions (Ma et al., 2019). In addition, transmission electron microscopy images (TEM) and Congo red binding assays of similar samples have indicated the formation of fibrils (ca. $10 \mathrm{~nm}$ in length) during the dry heating process (Ma et al., 2019).

Food protein fibrils, and in particular amyloid fibrils (AFs), have the potential to contribute to protein foaming, emulsifying and/or gelling properties (Jansens, Rombouts, et al., 2019). AFs are highly ordered nanostructures characterized by a cross- $\beta$ sheet core (Sunde et al., 1997). They can be formed during food processing (Jansens, Lambrecht, et al., 2019). For example, boiling induces the formation of AFs in native EW (Monge-Morera et al., 2020). In addition, processing conditions in terms of temperature, time, $\mathrm{pH}$, protein concentration, ionic strength, moisture content and heating mode, such as microwave heating (Zhang et al., 2020), influence AF formation (Jansens, Lambrecht, et al., 2019). Also, heating $2.0 \%(\mathrm{w} / \mathrm{v}) \mathrm{OVA}$ at $78^{\circ} \mathrm{C}$ for $22 \mathrm{~h}$ and neutral $\mathrm{pH}$ results in worm-like protein fibrils of predominantly $c a .<120 \mathrm{~nm}$ in length but also in larger ones $(c a .>200 \mathrm{~nm})$. Boiling OVA solutions for 15 min under similar conditions results in smaller ( $c a .80 \mathrm{~nm}$ in length) worm-like fibrils (MongeMorera et al., 2020). As the denaturation temperature of OVA is $c a .80^{\circ} \mathrm{C}$ at neutral $\mathrm{pH}$, boiling may not be ideal for its fibrillation (Jansens, Lambrecht, et al., 2019). OVA thermal unfolding results in more of its negatively charged and hydrophobic amino acids being exposed at the protein surface (Lambrecht et al., 2017). This can lead to fast and disordered aggregation, and thus hinder fibrillation (Eisele et al., 2015).

In addition, EW proteins usually form fibrillary structures when submitted to moderate heating (e.g. 65 to $85^{\circ} \mathrm{C}$ ) at pH values differing from its isoelectric point (pl 4.5) (Jansens, Lambrecht, et al., 2019). 
For EW proteins to fibrillate, the choice of temperature $\left(60\right.$ to $80^{\circ} \mathrm{C}$ ) is more important than protein concentration ( 0.5 to $20 \mathrm{mg} / \mathrm{ml}$ ) or ionic strength ( 0 to $200 \mathrm{mM} \mathrm{NaCl}$ ). Indeed, higher levels of cross $\beta$ sheet structures [estimated based on thioflavin T (ThT) fluorescence (Vassar \& Culling, 1959)] are formed in OVA and EW solutions $(20 \mathrm{mg} / \mathrm{ml}, \mathrm{pH} 7.5,200 \mathrm{mM} \mathrm{NaCl})$ heated for $30 \mathrm{~min}$ at $80^{\circ} \mathrm{C}$ than at $60{ }^{\circ} \mathrm{C}$ (Pearce et al., 2007). Nonetheless, optimal processing conditions for protein fibrillation of EW within the boundaries of food processing remain unknown.

Against this background, the present work was carried out

(i) to verify whether freeze-drying or spray-drying result in EW protein fibrillation,

(ii) to optimize the processing conditions for AF formation in solutions of OVA and EW proteins within common food processing boundaries, and

(iii) to study the impact of dry heating of EW powders on protein fibrillation in rehydrated EW.

During the different stages of this study, cross $\beta$-sheet rich structures were detected with ThT fluorescence as well as with Fourier transform infrared spectroscopy (FTIR) measurements and the size and morphology of the aggregates were studied with size exclusion high performance liquid chromatography (SE-HPLC) and TEM, respectively.

\section{Materials and Methods}

\subsection{Materials}

Hen eggs were from a local supermarket, stored at $4{ }^{\circ} \mathrm{C}$ and used within three weeks after being layed. EW was isolated from commercial eggs as commonly done (i.e. fresh EW). It was flash frozen with liquid nitrogen, freeze-dried, ground in a laboratory mill (IKA, Staufen, Germany) and passed through a $250 \mu \mathrm{m}$ sieve. The resulting freeze-dried EW (EWFD contained ca. 83\% of protein on dm (Figure 1). Industrially spray-dried EW (EW $\mathrm{SD}_{\mathrm{S}}$; protein content $c a .89 \%$ on $\mathrm{dm}$ ) and variants thereof which after spray-drying had been dry-heated for seven days at $50{ }^{\circ} \mathrm{C}$ and $50 \% \mathrm{RH}\left(\mathrm{EW}_{\mathrm{SD}} 50^{\circ} \mathrm{C} / 50 \%\right)$ or at $60{ }^{\circ} \mathrm{C}$ and $80 \% \mathrm{RH}\left[\mathrm{EW}_{\mathrm{SD}} 6^{\circ} \mathrm{C} / 80 \%\right.$ ] were obtained from Lodewijckx [Veerle-Laakdal, Belgium] (Figure 1). Dithiothreitol and sodium azide were from Acros Organic (Geel, Belgium). Sodium dodecyl sulfate and sodium dihydrogen phosphate dihydrate was from VWR International (Leuven, Belgium). Freeze-dried OVA [OVA $A_{\mathrm{FD}}$, albumin chicken egg grade III, protein content $c a$. $94 \%$ protein on $\mathrm{dm}$ basis, catalogue number A5370) and all other chemicals and reagents were of at least analytical grade and from SigmaAldrich (Bornem, Belgium). The highly amylogenic peptide (residues: 103-112, i.e. NFNYNNNLQG) derived from sup35 yeast protein was produced in-house according to Maurer-Stroh et al. (2010). 
107 Figure 1 shows the experimental set-up followed to study protein fibrillation in solutions of previously 108 dried EW. First, the levels of protein fibrils in aqueous solutions of fresh EW, EW FD and EW $\mathrm{ED}_{S \mathrm{C}}$ were 109 investigated. For this, aqueous solutions containing $2.0 \%(\mathrm{w} / \mathrm{v})$ fresh $E \mathrm{~W}, \mathrm{EW}_{\mathrm{FD}}$ and $\mathrm{EW}_{\mathrm{SD}}$ were 110 prepared in triplicate, vigorously vortexed and analyzed with FTIR spectroscopy (see section 2.9) and

111 TEM (see section 2.10). Second, the optimal fibrillation conditions in aqueous solutions of OVA $A_{F D}$ and $112 \mathrm{EW} \mathrm{FD}_{\mathrm{F}}$ were studied using a response surface design (see section 2.3). Third, the effect of dry heating on 113 fibrillation during heating in excess water was investigated for $\mathrm{EW}_{\mathrm{SD}} 50^{\circ} \mathrm{C} / 50 \%$ and $\mathrm{EW}_{\mathrm{SD}} 60^{\circ} \mathrm{C} / 80 \%$ (see section $114 \quad 2.4)$

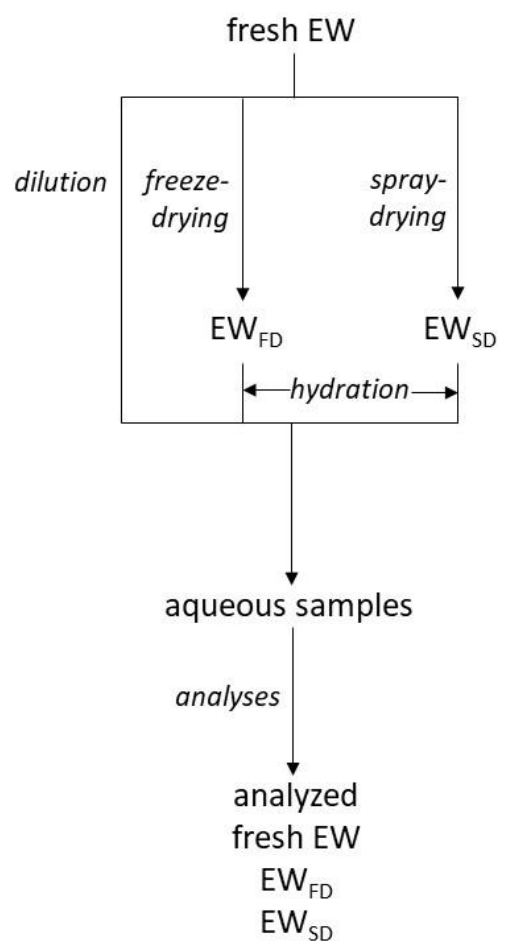

116

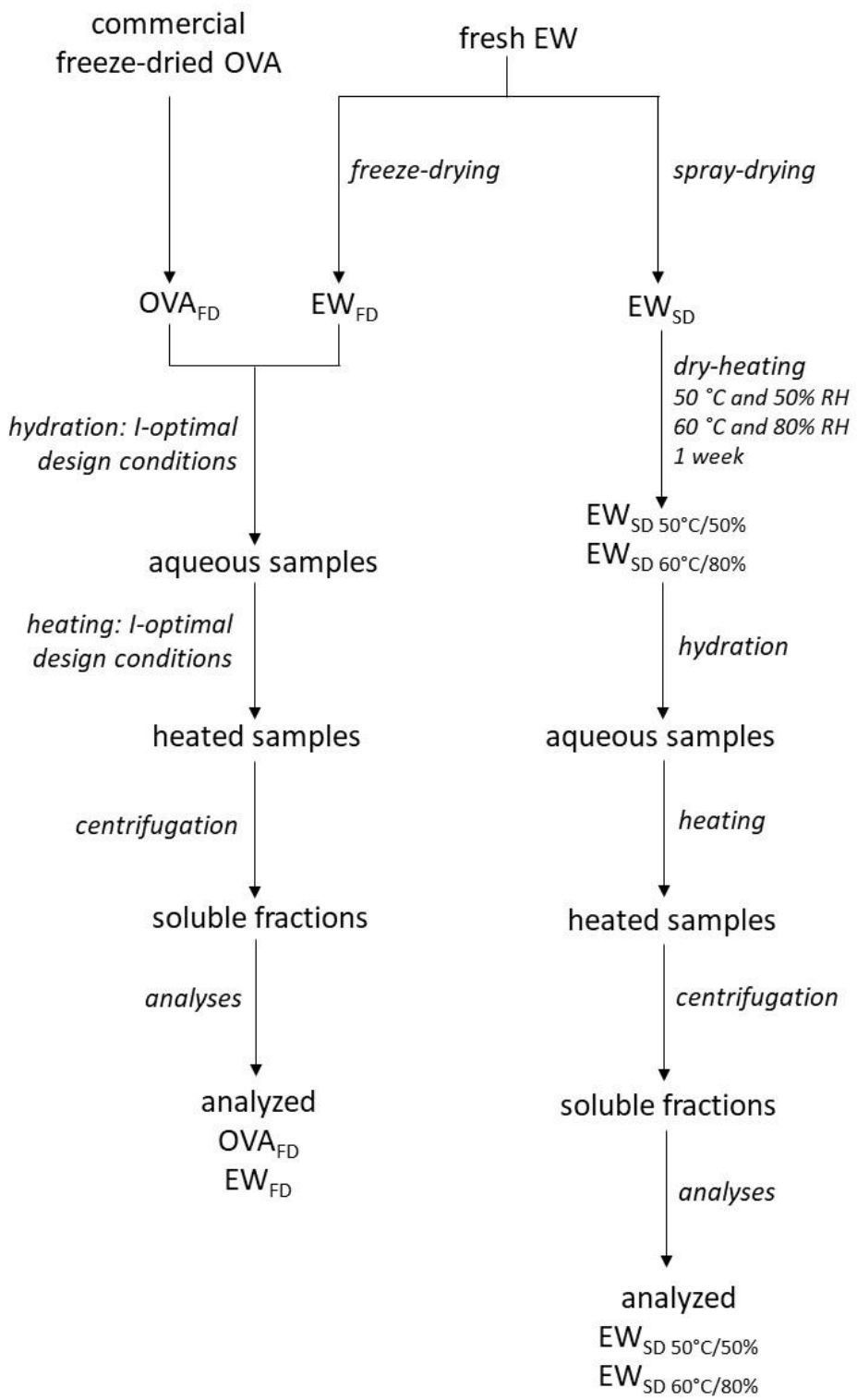


Figure 1. Experimental set-up for (left) studying protein fibrillation in freeze-dried (EW $F D$ ) and spray-dried (EWSD) egg white $(E W)$, (middle) optimizing the fibrillation conditions of freeze-dried ovalbumin (OVA $A_{F D}$ ) and $E W_{F D}$, (right) studying the impact of dry heating of $E W_{S D}$ at $50^{\circ} \mathrm{C}$ and $50 \%$ relative humidity $(R H)$ [ $\mathrm{EW}_{\mathrm{SD}} 50^{\circ} \mathrm{C} / 50 \%$ ] and at $60^{\circ} \mathrm{C}$ and $80 \%$ relative humidity $\left(\mathrm{EW}_{\mathrm{SD}}\right.$ $60^{\circ} \mathrm{C} / 80 \%$ ) on protein fibrillation.

\subsection{Experimental design for the optimization of the processing conditions}

A response surface design selected using the I-optimality criterion was used to identify the conditions under which $\mathrm{OVA}_{\mathrm{FD}}$ and $\mathrm{EW}_{\mathrm{FD}}$ solutions lead to maximum ThT fluorescence as a measure for $\mathrm{AF}$ formation (Figure 1). The experimental design considers factor main effects, interaction effects and quadratic effects (Goos \& Jones, 2011). The processing conditions studied were protein concentration, $\mathrm{pH}$, temperature and time. The protein concentration ranged from $0.5 \%$ to $2.0 \%\left(\mathrm{w}_{\text {protein }} / \mathrm{v}\right)$, the $\mathrm{pH}$ from 5.0 to 7.0 , the temperature from 65 to $85^{\circ} \mathrm{C}$ and the time from 0 to $24 \mathrm{~h}$. In the experiment, 40 different factor level combinations were evaluated. Aqueous samples $[1.5 \mathrm{ml}$, containing $0.02 \%(\mathrm{w} / \mathrm{v})$ sodium azide] were heated while shaking at $70 \mathrm{rpm}$. They were then cooled on ice-water and centrifuged $(9,300 \mathrm{~g}, 10 \mathrm{~min}$, room temperature). The protein contents (see section 2.5) and ThT fluorescence intensities (see section 2.6) of the supernatants were analyzed. The resultant ThT fluorescence values were used to fit a surface model using ordinary least squares regression to identify significant effects $(P<0.05)$. The full response surface model was fitted and insignificant effects were removed by backward model selection. The model fit was evaluated based on the coefficient of determination $\left(R^{2}\right)$ and the actual-by-predicted plot, which compares the observed and the predicted response values. Selected samples were submitted to FTIR spectroscopy (see section 2.9) and TEM (see section 2.10).

\subsection{Heat treating egg white dispersions}

$\mathrm{EW}_{\mathrm{SD}}, \mathrm{EW}_{\mathrm{SD} 50^{\circ} \mathrm{C} / 50 \%}$ and $\mathrm{EW}_{\mathrm{SD}} 60^{\circ} \mathrm{C} / 80 \%$ (see section 2.1) were heated using the above optimized processing conditions for protein fibril formation: $0.5 \%\left(\mathrm{w}_{\text {protein }} / \mathrm{v}\right)$ in deionized water (containing $0.02 \%(\mathrm{w} / \mathrm{v})$ sodium azide) at $\mathrm{pH} 7.3$ and heated at $85{ }^{\circ} \mathrm{C}$ for $24 \mathrm{~h}$ (Figure 1). The $\mathrm{pH}$ of EW samples was adjusted with $0.01 \mathrm{M}$ of hydrochloric acid. After heating, samples were cooled on ice-water and centrifuged $(9,300 \mathrm{~g}, 10 \mathrm{~min}$, room temperature). The soluble fractions were analyzed for protein content (see section 2.5), ThT fluorescence (see section 2.6) and protein apparent molecular weight (MW) distribution (see section 2.7). Selected samples were analyzed using FTIR spectroscopy (see section 2.9) and TEM (see section 2.10).

\subsection{Analysis of protein content}

The protein contents of diluted OVA and EW extracts [ca. $\left.0.1 \%\left(\mathrm{w}_{\text {protein }} / \mathrm{v}\right)\right]$ were determined in triplicate by analysis of ultraviolet (UV) extinction ( $280 \mathrm{~nm}$ ). Samples were analyzed in UV-star plates (Greiner Bio-One, Vilvoorde, Belgium) as indicated previously (Monge-Morera et al., 2020) using a 
Synergy Multi-Mode Microplate Reader (BioTek, Winooski, VT, USA). Absorbance values were converted to protein concentrations using a calibration curve with unheated OVA and EW $S\left(R^{2}=0.9987\right.$ and $R^{2}=0.9988$; respectively).

\subsection{Analysis of thioflavin T fluorescence}

ThT fluorescence measurements were used as an indication for the levels of cross- $\beta$ sheet structures. In a black 96-well plate (Greiner Bio-One), samples were prepared as in Monge-Morera et al. (2020) and measured in triplicate in a Synergy Multi-Mode Microplate Reader (BioTek). The excitation and emission wavelengths were $440 \mathrm{~nm}$ and $480 \mathrm{~nm}$, respectively. ThT fluorescence is expressed as the fluorescence intensity of the sample relative to that of the above mentioned sup35 yeast peptide (Maurer-Stroh et al., 2010).

\subsection{Size exclusion chromatography}

The apparent molecular weight (MW) distribution of $\mathrm{EW}_{\mathrm{SD}}$ protein aggregates was evaluated in triplicate using size exclusion high performance liquid chromatography (SE-HPLC). Sample (EW $\mathrm{SD}$, EW $50^{\circ} \mathrm{C} / 50 \%$ and $\mathrm{EW}$ SD $60^{\circ} \mathrm{C} / 80 \%$ ) aliquots containing $1.0 \mathrm{mg}$ protein were mixed with $1.0 \mathrm{ml} 0.05 \mathrm{M}$ sodium phosphate buffer pH 6.8 (SPB) containing $2.0 \%(\mathrm{w} / \mathrm{v})$ sodium dodecyl sulfate (SDS) to extract protein under non-reducing conditions by shaking (60 min, $150 \mathrm{rpm}$, room temperature). Marker proteins were phosphorylase b (97 kDa), OVA (44 kDa) and aprotinin (6.5 kDa). Proteins were also extracted under nitrogen atmosphere under reducing conditions, i.e. using SPB containing 2.0\% (w/v) SDS and $2.0 \%(\mathrm{w} / \mathrm{v})$ dithiothreitol. After centrifugation $(9,300 \mathrm{~g}, 10 \mathrm{~min}$, room temperature) and filtration (Millex-HP, $0.45 \mu \mathrm{m}$, polyethersulfone; Millipore, Carrigtwohill, Ireland), extracts ( $20 \mu \mathrm{L}$ ) were loaded on a Biosep-SEC-S4000 (size range 15-1,500 kDa) column (Phenomenex, Torrance, CA, USA) at $30^{\circ} \mathrm{C}$. The eluent $(1.0 \mathrm{ml} / \mathrm{min})$ was SPB containing $2.0 \%(\mathrm{w} / \mathrm{v})$ SDS. SE-HPLC was conducted in a Shimadzu (Kyoto, Japan) Prominence modular system with automated injection and protein elution was monitored at $214 \mathrm{~nm}$. The MW distribution shown in Figure 7 contain one representative profile.

The apparent MW distribution of (un)heated $\mathrm{EW}_{\mathrm{SD}}, \mathrm{EW}_{\mathrm{SD}} 50^{\circ} \mathrm{C} / 50 \%$ and $\mathrm{EW}_{\mathrm{SD}} 60^{\circ} \mathrm{C} / 80 \%$ (see section 2.4) was also monitored with both UV (at $280 \mathrm{~nm}$ ) and ThT fluorescence measurements (with 450 and $480 \mathrm{~nm}$ as excitation and emission wavelengths, respectively) as described in Monge-Morera et al. (2020). In this case, samples $(25 \mu \mathrm{l})$ were loaded on the same column type, eluted at $30^{\circ} \mathrm{C}$ and the analysis was performed using a modular system similar to the above one. One representative sample of the MW distribution (monitored both with UV and ThT fluorescence) is shown in Figure 8.

\subsection{Differential scanning calorimetry}

Protein denaturation properties were determined in triplicate using differential scanning calorimetry with a Q2000 DSC (TA instruments, New Castle, DE, USA). EW 
(3.0 to $4.0 \mathrm{mg}$ ) were accurately weighed in an aluminum pan (Hitachi High-Technologies, Tokyo, Japan) and deionized water $[1 / 3(\mathrm{w} / \mathrm{w}) \mathrm{dm}$ protein/water] was added. Pans were hermetically sealed and heated from $0{ }^{\circ} \mathrm{C}$ to $120^{\circ} \mathrm{C}$ at $4^{\circ} \mathrm{C} / \mathrm{min}$. Empty pans were used as reference. The denaturation onset, peak, conclusion temperatures, temperature ranges and enthalpies were determined using Universal Analysis 2000 software (TA Instruments).

\subsection{Attenuated total reflection Fourier transform infrared spectroscopy}

The secondary structure of at least duplicates aqueous samples $\left(35 \mu \mathrm{l}, 0.1 \%\left(w_{\text {protein }} / v\right)\right)$ of fresh EW, (un)heated $\mathrm{OVA}_{\mathrm{FD}}$ and $\mathrm{EW}_{\mathrm{FD}}$ and (un)heated $\mathrm{EW}_{\mathrm{SD}}, \mathrm{EW}_{\mathrm{SD} 50^{\circ} \mathrm{C} / 50 \%}$ and $\mathrm{EW}_{\mathrm{SD}} 60^{\circ} \mathrm{C} / 80 \%$ (see sections 2.2 to 2.4) was investigated with attenuated total reflection FTIR spectroscopy (ATR-FTIR) in a Bruker (Karlsruhe, Germany) Tensor 27 infrared spectrophotometer equipped with a Bio-ATR II accessory (Harrick Scientific Products, Pleasantville, NY, USA) as indicated in Monge-Morera et al. (2020). One representative spectrum is shown in Figure 3 and 6, and maximum peaks were assigned with peak picking based on the second derivative as implemented in Bruker OPUS software.

\subsection{Transmission electron microscopy}

The morphology of protein aggregates was visualized with TEM using negative staining with uranyl acetate of a single preparation. Samples were prepared as indicated in Monge-Morera et al. (2020) and examined using a JEM-1400 TEM (Jeol, Tokyo, Japan) at $80 \mathrm{keV}$. The average length of the protein aggregates was determined with Image J 1.52a software (National Institutes of Health, Bethesda, MD, USA) using at least three TEM images taken from a single preparation and measuring at least ten different aggregates in them.

\subsection{Statistics}

The experimental design construction and the estimation of the response surface models for protein fibril formation was done with the JMP ${ }^{\circledR}$ Pro 14.0.0 software (SAS Institute, Cary, NC, USA). For the ThT fluorescence response variable, the natural logarithm (Ln) was modeled to obtain strictly positive predictions for any processing condition under study. Significant differences $(P<0.05)$ based on at least three individual measurements were determined with one-way ANOVA procedure using JMP ${ }^{\circledR}$ Pro 14.0.0. Corresponding Tukey grouping coefficients are given.

\section{Results and discussion}

3.1 Impact of drying on egg white protein fibrillation

Solutions/dispersions of dried EW were compared with fresh EW to study the impact of freeze- and spray-drying on EW protein fibrillation. FTIR was used to measure the level of $\beta$-sheet structures and 
216 TEM to evaluate the morphology of the protein aggregates. For fresh EW, TEM images of aqueous 217 dispersions containing $0.1 \%(\mathrm{w} / \mathrm{v})$ protein showed the presence of only amorphous protein aggregates 218 (Figures 2 and 1S). In contrast, protein fibrils were present in similar (unheated) solutions/dispersions 219 of $\mathrm{EW}_{\mathrm{FD}}$ or $\mathrm{EW}_{\mathrm{SD}}$ in water (Figures 2 and $1 \mathrm{~S}$ ). While $\mathrm{EW}_{\mathrm{FD}}$ contained small worm-like protein fibrils (ca. 20 to $100 \mathrm{~nm}$ long) in combination with large amorphous aggregates (ca. 150 to $400 \mathrm{~nm}$ long), EW SD contained larger worm-like protein fibrils (ca. 100 to $200 \mathrm{~nm}$ ) and amorphous aggregates of similar size (Figures 2 and 1 S).

223 In addition, comparison of the FTIR spectra of EW FD and EW 224 former were slightly shifted to lower wavenumbers, indicating an increased order in secondary protein 225 structure (Figure 3.A). $\beta$-Sheet structures result in characteristics wavenumbers in the regions 1,696 \pm $2262.0 \mathrm{~cm}^{-1}$ to $1,667 \pm 1.0 \mathrm{~cm}^{-1}$ and $1,642 \pm 1.0 \mathrm{~cm}^{-1}$ to $1,624 \pm 1.0 \mathrm{~cm}^{-1}$ (Kong \& Yu, 2007). However, when $\beta$-sheet structures are part of AFs, there is a shift towards lower wavenumbers (ca. 1,630 and ca. 1,611 $\mathrm{cm}^{-1}$ ) (Zandomeneghi et al., 2009). FTIR spectra of both EWFD and EW wavenumbers (i.e. 1,634 and 1,618 $\mathrm{cm}^{-1}$ ), which were more prominent for $\mathrm{EW}_{\mathrm{SD}}$ than for $\mathrm{EW}_{\mathrm{FD}}$, and pointed to the potential organization into amyloid proteins. During spray-drying and freeze-drying of EW (partial) protein denaturation occurs which leads to formation of protein aggregates (Chen et al., 2012; Lechevalier et al., 2007). The extent to which this happens is normally larger during spray-drying than during freeze-drying of EW (Chen et al., 2012; Lili et al., 2015), which suggests that the level of denaturation during these processes may play a role in EW protein fibrillation. As far as the authors are aware, the here reported observation that spray-drying and freeze-drying induce the formation of protein fibrils in EW and that those induced by spray-drying are larger than those induced by freezedrying are totally novel and supplement the recent second report that relevant food processing conditions induce EW protein fibrillation (Monge-Morera et al., 2020). 

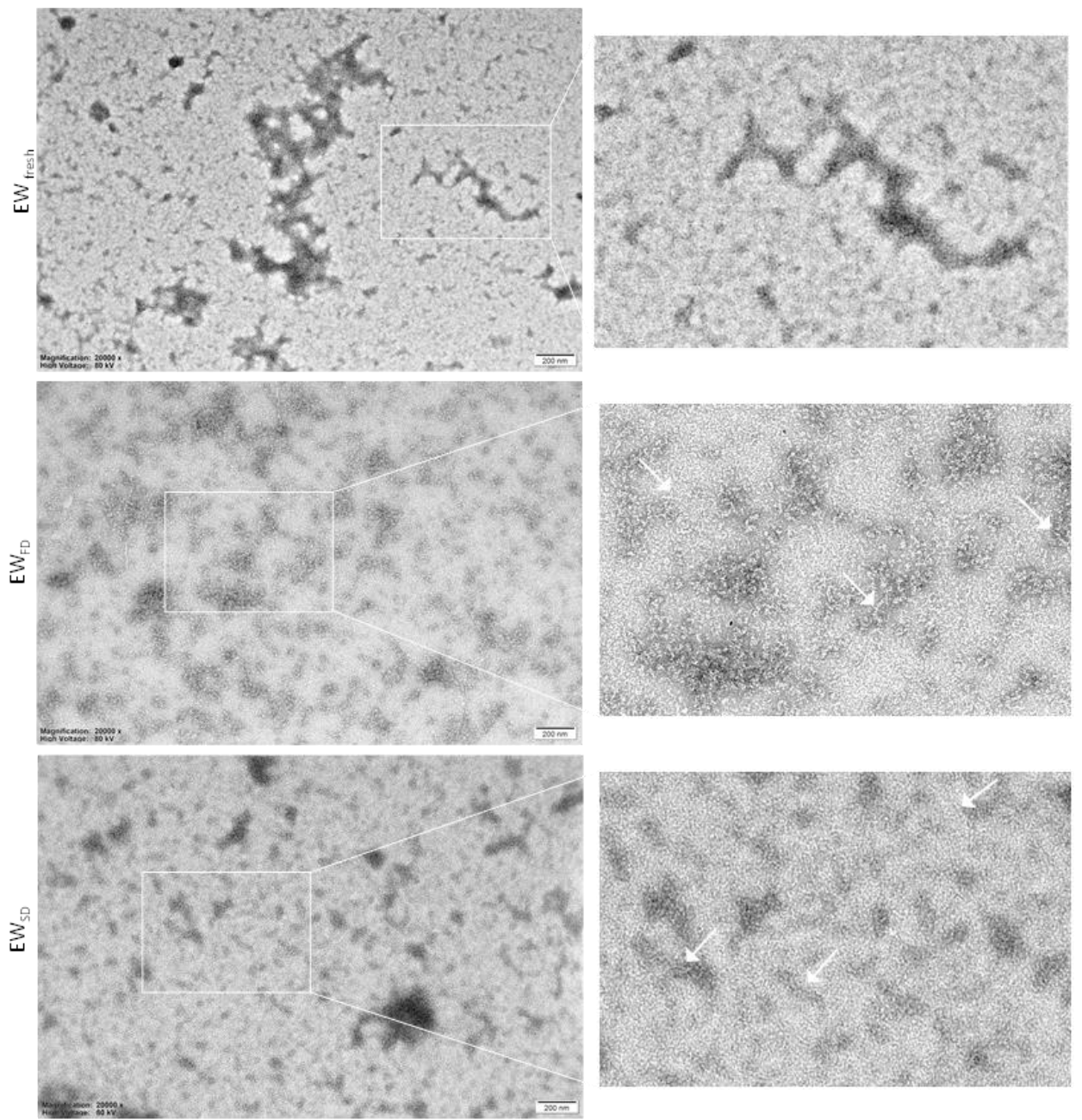

Figure 2. Transmission electron microscopy (TEM) images of unheated aqueous protein solutions/dispersions containing $0.1 \%$ $(\mathrm{w} / \mathrm{v})$ fresh, freeze-dried (FD) or spray-dried (SD) egg white (EW) protein. Scale bar: $200 \mathrm{~nm}$. Protein fibrils are marked with white arrows.
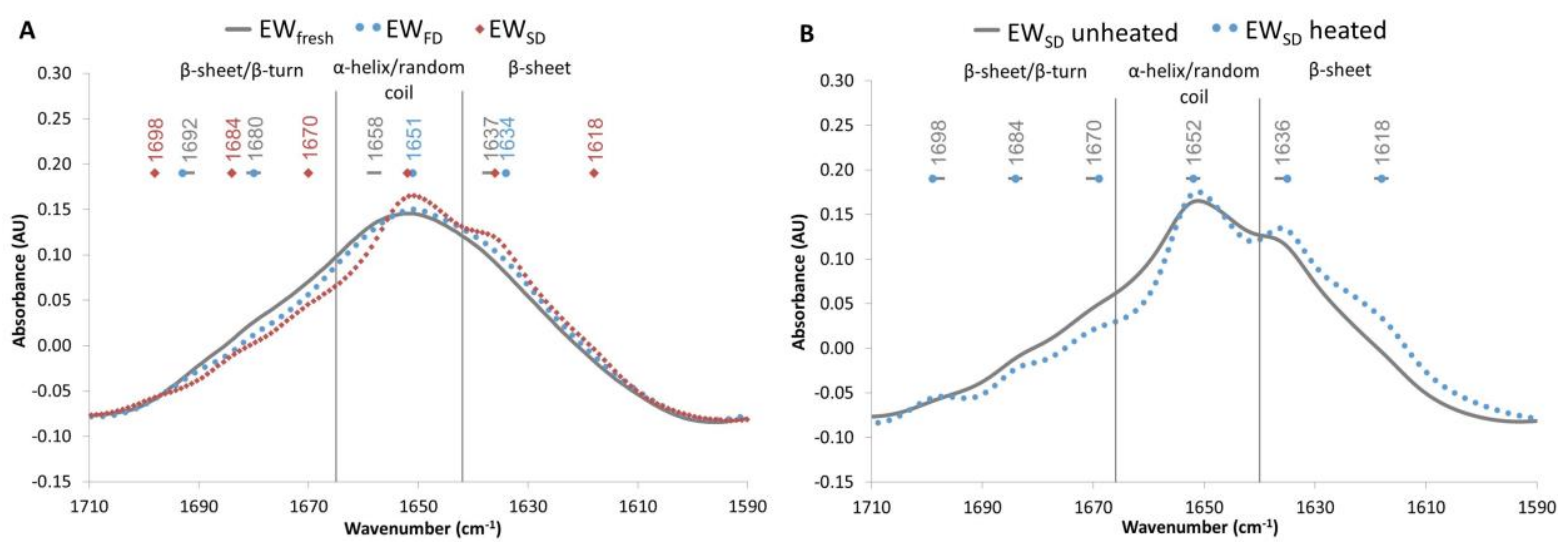

Figure 3. Fourier transform infrared (FTIR) spectra of aqueous proteins solutions/dispersions of fresh, freeze-dried (FD) and spray-dried (SD) egg white (EW) [A]. FTIR spectra of unheated EW $W_{S D}\left[0.5 \%\left(w_{\text {protein }} / v\right)\right]$ and the same sample heated for $24 \mathrm{~h}$ at $85^{\circ} \mathrm{C}$ and $\mathrm{pH} 7.0(\mathrm{~B})$. Wavenumbers of the FTIR spectra were determined with a peak picking tool based on the second derivative of these curves. The vertical lines attribute ranges of wavenumbers to specific secondary structures of proteins. $A U$, arbitrary units. 
3.2 Optimal conditions for ovalbumin and egg white fibrillation The impact of protein concentration [0.5\% to $2.0 \%(\mathrm{w} / \mathrm{v})], \mathrm{pH}$ (5.0 to 7.0$)$, heating temperature (65 to $85^{\circ} \mathrm{C}$ ) and time ( 0 to $24 \mathrm{~h}$ ) on protein fibrillation was monitored with ThT fluorescence measurements. The optimal fibrillation conditions within the given ranges, yet still relevant for food processing, for $\mathrm{EW}_{\mathrm{FD}}$ and OVA were identified using and response surface design.

For $O V A_{F D}$, temperature had a significant quadratic effect $(P=0.00022)$ with a maximum predicted ThT fluorescence at $76^{\circ} \mathrm{C}$ as shown in Figure 4.A. This is probably related to unfolding and denaturation of OVA. At $65^{\circ} \mathrm{C}$ the native conformation of OVA is still preserved (Tani et al., 1997) and protein fibrillation is less pronounced as indicated by the low ThT fluorescence values. At neutral pH OVA starts unfolding around $71^{\circ} \mathrm{C}$ (Photchanachai et al., 2002) and is fully denaturated at $c a .80^{\circ} \mathrm{C}$ (Lambrecht et al., 2017). Partial protein unfolding (Jansens, Lambrecht, et al., 2019) and the subsequent exposure of high aggregation prone regions promote protein fibrillation (Tanaka et al., 2011). It thus is not surprising

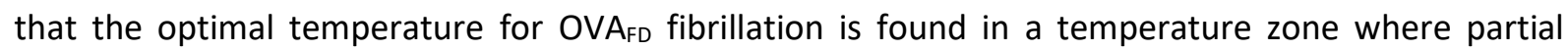
unfolding has occurred rather than at or above the denaturation temperature. In samples at temperatures exceeding $80^{\circ} \mathrm{C}$, lower ThT fluorescence was observed, which suggested the presence of amorphous structures instead of amyloid-like fibrils.

The $\mathrm{pH}$ level $(P<0.00040)$ had a significant positive effect on ThT fluorescence of OVA $A_{F D}$. Neutral pH resulted in the highest predicted ThT fluorescence, while $\mathrm{pH}$ values (i.e. 5.0) closer to the $\mathrm{pl}$ of OVA (4.5) led to the lowest predicted ThT fluorescence values (Figures 4.A and 1S.A1). Close to the isoelectric point, proteins aggregate easily but also more randomly, which hinders fibrillation. The latter no longer held around neutral pH. Similarly, heating time $(P<0.00001)$ had a significant positive effect on ThT fluorescence (Figure 4.A), which is easily rationalized by invoking earlier insights that protein fibril formation is usually slow (Lambrecht et al., 2019) and requires the presence of a stable $\beta$-aggregated amyloid precursor (Rousseau et al., 2006).

Protein concentration was not a significant main effect in the model. However, it had a significant interaction $(P=0.01785)$ with $\mathrm{pH}$ (Figure 4.A). While the predicted ThT fluorescence at $0.5 \%\left(\mathrm{w}_{\text {protein }} / \mathrm{v}\right)$ did not strongly depend on the $\mathrm{pH}$, at $2.0 \%\left(\mathrm{w}_{\text {protein }} / \mathrm{v}\right)$ the predicted ThT fluorescence was much higher at $\mathrm{pH} 7.0$ than at pH 5.0 (Figure 1S.B1). The maximum ThT fluoresence was achieved when $2.0 \%(\mathrm{w} / \mathrm{v})$ $\mathrm{OVA}_{\mathrm{FD}}$ protein solution was heated at neutral $\mathrm{pH}$ and $76^{\circ} \mathrm{C}$ for $23 \mathrm{~h}$ (Figure 4.A). Unheated solutions of $\mathrm{OVA}_{\mathrm{FD}}$ contained mainly amorphous aggregates (Figures 5 and $2 \mathrm{~S}$ ), whereas heating at the optimal conditions resulted in additional worm-like protein fibrils with lengths in a 60 to $150 \mathrm{~nm}$ range (Figures 5 and 1S). FTIR spectra of both unheated and heated OVA $A_{F D}$ showed evidence for characteristic $\beta$-sheet structures (Figure 6.A). However, the spectrum of heated OVA $A_{F D}$ was shifted to lower wavenumbers 

secondary protein structures and the presence of $\beta$-sheet structures of amyloid-like nature as a result of the heating treatment (Figure 6.A).
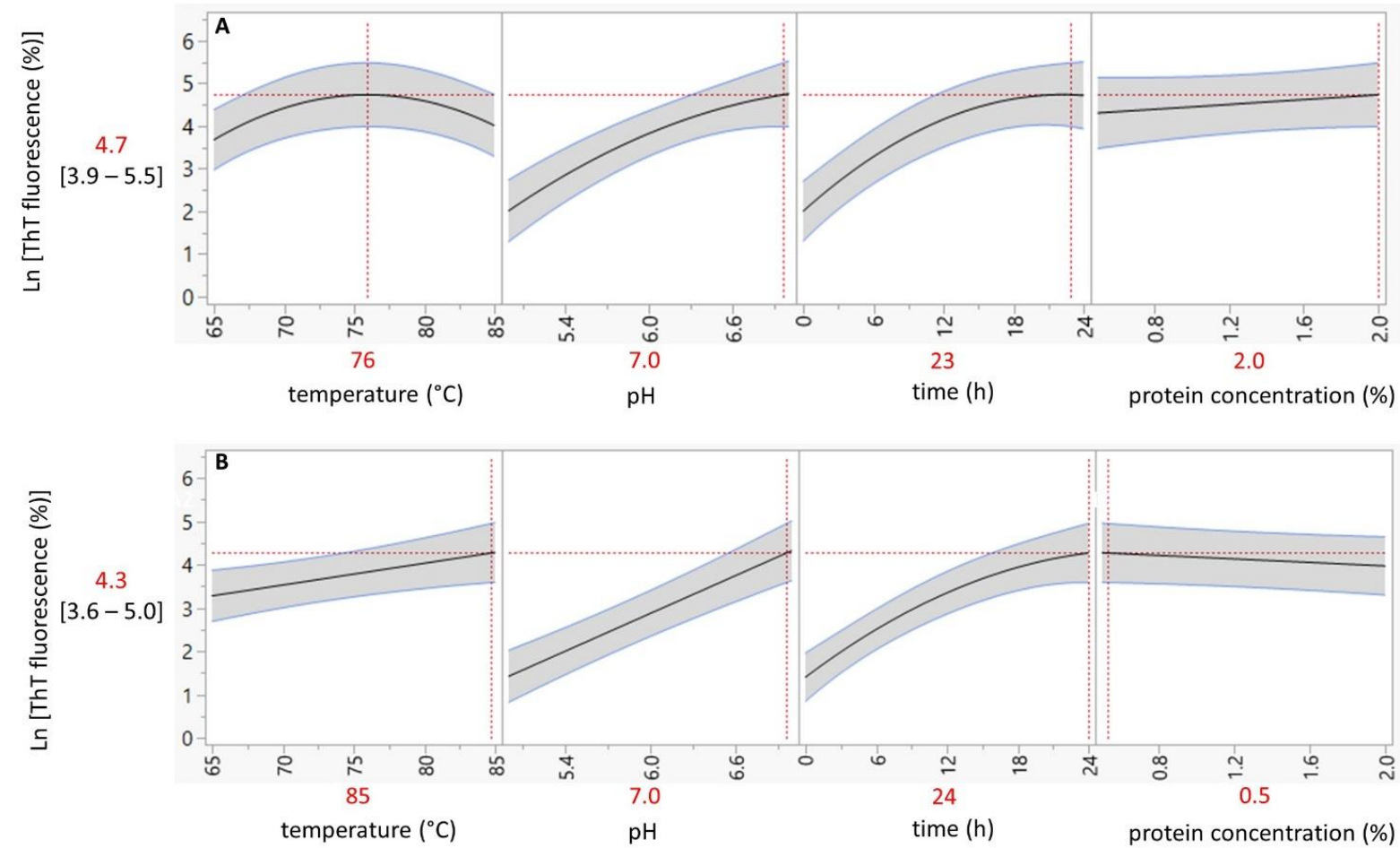

Figure 4. Prediction profiles of freeze-dried ovalbumin $\left(O V A_{F D}, A\right)$ and egg white $\left(E W_{F D}, B\right)$ soluble fractions showing the predicted natural logarithm (Ln) of thioflavin T (ThT) fluorescence as a function of temperature, $p H$, time and protein concentration. The incubation conditions that maximize ThT fluorescence are indicated in red. Confidence intervals are coloured in grey.

Figure 4.B shows that the optimal fibrillation conditions for $\mathrm{EW}_{\mathrm{FD}}$ were $0.5 \%\left(\mathrm{w}_{\text {protein }} / \mathrm{v}\right)$ at neutral $\mathrm{pH}$ and heating at $85{ }^{\circ} \mathrm{C}$ for $24 \mathrm{~h}$. Under such conditions, the maximum predicted ThT fluorescence for $\mathrm{EW}_{\mathrm{FD}}$ was lower than the predicted optimum for OVAFD. It was reported recently that the level of ThT fluorescence was higher for boiled OVA $[2.0 \%(\mathrm{w} / \mathrm{v})]$ at neutral $\mathrm{pH}$ than for EW boiled under similar conditions (Monge-Morera et al., 2020). In addition, the intensity of ThT fluorescence as a result of heating at $80^{\circ} \mathrm{C}$ for $30 \mathrm{~min}$ at $\mathrm{pH} 7.5$ was lower in EW than for OVA. These observations indicate that interactions between OVA and other EW proteins favour the formation of amorphous aggregates and in that way hinder fibrillation as suggested earlier by Pearce et al. (2007). In this context it is noteworthy that Weijers et al. (2006) showed that heating OVA at $78{ }^{\circ} \mathrm{C}$ for $22 \mathrm{~h}$ at pH 7.0 in the presence or absence of ovotransferrin resulted in large protein clusters (20 to $300 \mathrm{~nm}$ ) and semiflexible fibrils (300 - $1000 \mathrm{~nm}$ ), respectively.

While treatment temperature $(P=0.13497)$ did not have a significant main effect in the ThT fluorescence $E W_{F D}$ model, it did have a significant interaction effect with treatment time $(P=0.02268)$. For instance, the ThT fluorescence at shorter incubation times was similar irrespective of the 
temperature, whereas, at longer incubation times, the ThT fluorescence was much higher at $85^{\circ} \mathrm{C}$ than at $65^{\circ} \mathrm{C}$ (Figures 4.B and 1S.A2). As also noted for OVA $\mathrm{AD}_{\mathrm{FD}}$, treatment $\mathrm{pH}(P<0.000005)$ and time $(P<$ 0.00003) had a significant positive effect in the predicted ThT fluorescence EW FD model (Figure 4.B). Longer incubation times and neutral $\mathrm{pH}$ favoured $\mathrm{EW}_{\mathrm{FD}}$ protein fibrillation, while shorter times and lower $\mathrm{pH}$ values (i.e. $\mathrm{pH} 5.0$ and 6.0) resulted in significantly lower ThT fluorescence values (Figure 4.B). Disordered protein aggregates are rapidly formed at $\mathrm{pH}$ values close to the isoelectric point of the majority of the EW proteins [ca. 4 to 5] (Powrie \& Nakai, 1985). In addition, there was a significant interaction between treatment $\mathrm{pH}$ and heating time $(P<0.00003)$. The ThT fluorescence of $\mathrm{EWFD}_{\mathrm{FD}}$ at shorter incubation times was similar irrespective of the $\mathrm{pH}$, while, at longer incubation times, the ThT fluorescence was higher at neutral pH than at $\mathrm{pH} 5.0$ (Figure 4.B and Figure 1S.B2). Protein concentration did not have a significant effect $(P=0.18083)$ in the predicted ThT fluorescence EW $\mathrm{FD}$ model (Figure 4.B).

After subjecting unheated $\mathrm{EW}_{\mathrm{FD}}$ to their optimal conditions, TEM images showed the presence of amorphous structures in combination with small $(c a .50 \mathrm{~nm}$ ) worm-like protein fibrils (Figure 5 and Figure 2S), whereas heated EW FD showed mainly small $(c a .50 \mathrm{~nm})$ and some large $(c a .150 \mathrm{~nm})$ wormlike fibrils as well as some amorphous structures (Figures 5 and Figure 2S). Figure 6.B shows that the FTIR spectra of both unheated and heated EW FD contained $\beta$-sheet structures. However, the difference in the FTIR spectra of both heated and unheated $\mathrm{EW}_{\mathrm{FD}}$ at lower wavenumbers (i.e. $1625 \mathrm{~cm}^{-1}$ ) indicated a higher occurrence of ordered $\beta$-sheet structures as a result of the heating treatment.

Overall, both neutral $\mathrm{pH}$ and incubation times of $c a .24 \mathrm{~h}$ promoted OVA and EWFD protein fibrillation. Higher temperatures (i.e. $85{ }^{\circ} \mathrm{C}$ ) are needed for optimal $\mathrm{EW}_{\mathrm{FD}}$ protein fibrillation than for OVA fibrillation (i.e. $76{ }^{\circ} \mathrm{C}$ ). Protein concentration did not significantly affect OVA and $\mathrm{EW}_{\mathrm{FD}}$ protein fibrillation. Under the optimal conditions, $\mathrm{EW}_{\mathrm{FD}}$ protein fibrillation occurred to a smaller extent than that of OVAFD. Indeed, TEM images revealed less and shorter fibrillary structures in optimally heated $\mathrm{EW}_{\mathrm{FD}}$ than OVA $\mathrm{FD}_{\mathrm{FD}}$. The overlap of the X-ray diffraction patterns of heat-derived OVA and EW amyloid fibrils shown in Monge-Morera et al. (2020) suggest that OVA has a predominantly role in egg white protein fibrillation. Other proteins (e.g. ovotransferrin) in egg white can interact with OVA and limit the extent to which it fibrillates (Weijers et al., 2006). Nevertheless, interactions between lysozyme and ovalbumin during heating result in protein fibrils (Sugimoto et al., 2011). The formation of hydrophobic bonds between OVA and lysozyme causes this interaction (Jin et al., 2020). 

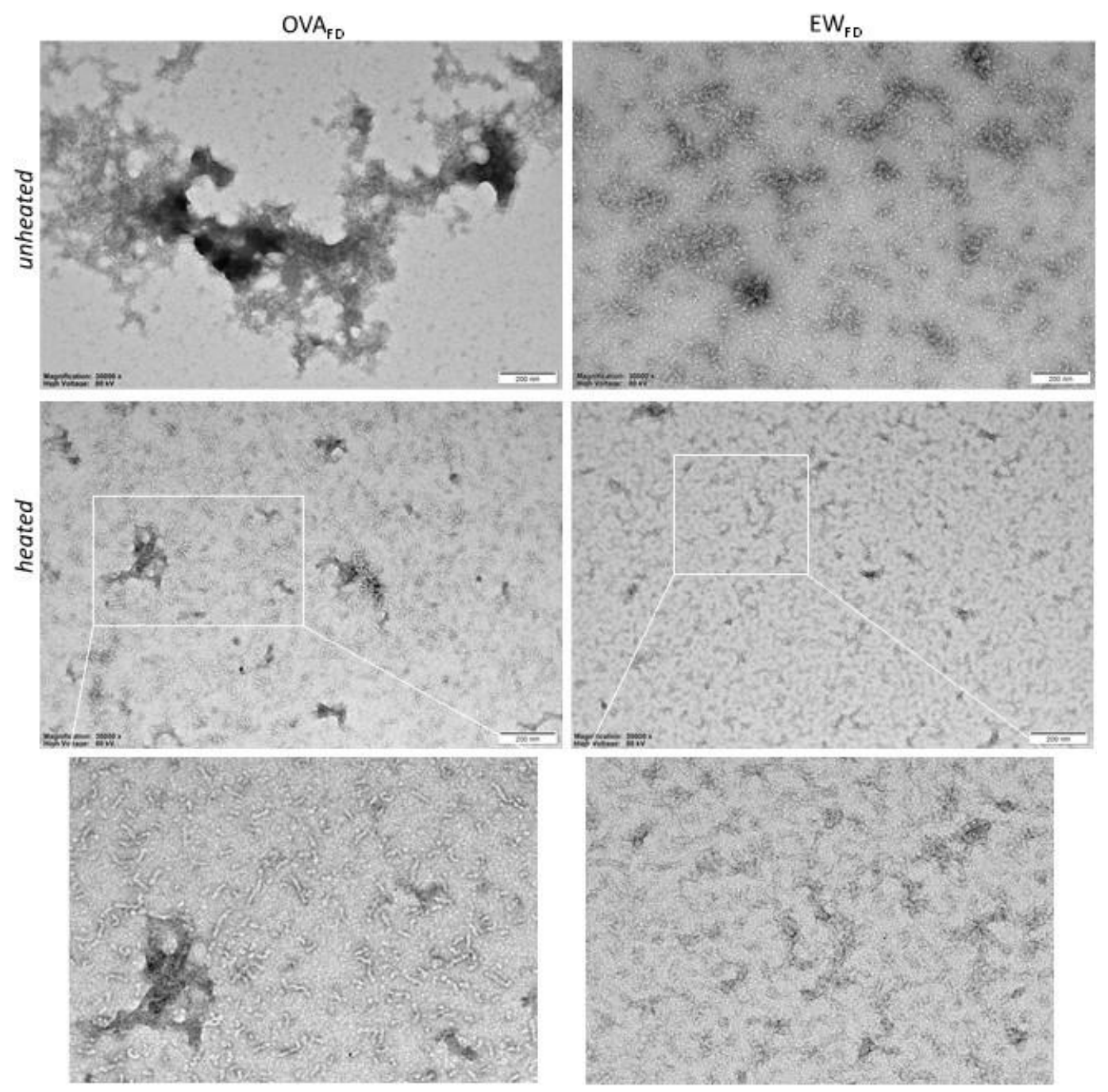

Figure 5. Transmission electron microscopy (TEM) images of unheated and heated freeze-dried ovalbumin (OVA $A_{F D}$ ) and egg white $\left(E W_{F D}\right)$ soluble fractions. Ovalbumin [OVA, $\left.2.0 \%(\mathrm{~W} / \mathrm{V})\right]$ was heated for $23 \mathrm{~h}$ at $76{ }^{\circ} \mathrm{C}$ and $\mathrm{pH} 7.0$ and egg white (EW) protein $[0.5 \%(\mathrm{w} / \mathrm{v})]$ was heated for $24 \mathrm{~h}$ at $85^{\circ} \mathrm{C}$ and $\mathrm{pH}$ 7.0. Scale bar: $200 \mathrm{~nm}$.
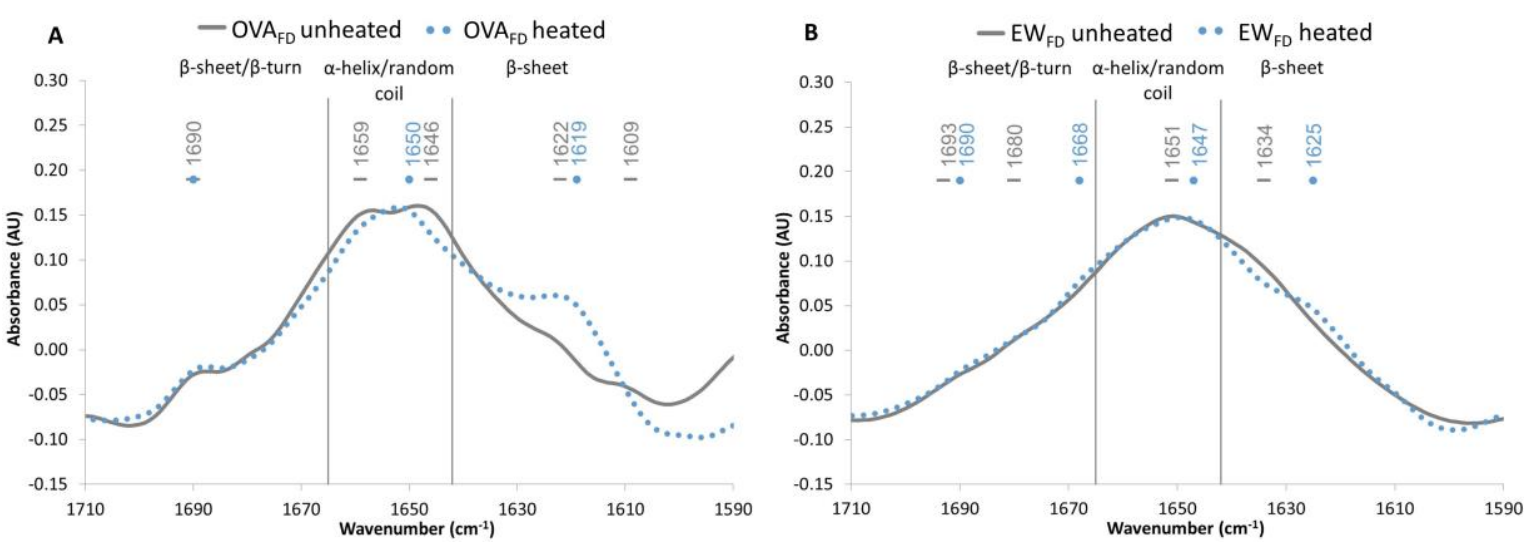

Figure 6. Fourier transform infrared (FTIR) spectra of unheated and heated aqueous proteins solutions/dispersions of freezedried ovalbumin (OVA $\left.A_{F D}, A\right)$ and freeze-dried egg white $\left(E W_{F D}, B\right)$ soluble fractions. Ovalbumin [OVA, 2.0\% $\left.(W / v)\right]$ was heated for $23 \mathrm{~h}$ at $76{ }^{\circ} \mathrm{C}$ and $\mathrm{pH} 7.0$ and egg white (EW) protein $[0.5 \%(\mathrm{~W} / \mathrm{V})]$ for $24 \mathrm{~h}$ at $85^{\circ} \mathrm{C}$ and $\mathrm{pH} 7.0$. Wavenumbers of the FTIR spectra were determined with a peak picking tool based on the second derivative of these curves. The vertical lines attribute ranges of wavenumbers to specific secondary structures of proteins. AU, arbitrary units. 
3.3 Impact of dry heating on heat-induced egg white protein fibrillation

350 Dry heating of $\mathrm{EW}$ SD at temperatures exceeding $60^{\circ} \mathrm{C}$ and controlled relative humidity $(>65 \%)$ for 3 up 351 to 30 days promotes protein unfolding and enhances protein aggregation (Baron et al., 2003; Ma et al., 2019). We here hypothesized that such pre-treatment also enhances protein fibrillation during subsequent heating in excess water. To that end, solutions/dispersions of $\mathrm{EW}_{\mathrm{SD}} 50^{\circ} \mathrm{C} / 50 \%$ and $\mathrm{EW}$ SD $60^{\circ} \mathrm{C} / 80 \%$ samples were investigated before and after additional heating.

355

First, the properties of these samples were determined to link them to their ability to form fibrils. Differential scanning calorimetry showed two denaturation peaks around 64.5 and $82.2^{\circ} \mathrm{C}$ for $\mathrm{EW}_{S D}$ and $\mathrm{EW}_{\mathrm{SD}} 50^{\circ} \mathrm{C} / 50 \%$. These peaks have been attributed to denaturation of mainly ovotransferrin and ovalbumin, respectively (Donovan et al., 1975). $\mathrm{EW}_{\mathrm{SD} 60^{\circ} \mathrm{C} / 80 \%}$ no longer showed the denaturation peak of ovotransferrin while the peak of mainly ovalbumin occurred at a slightly higher temperature (83.1 $\pm 0.1^{\circ} \mathrm{C}$ ). In addition, $\mathrm{SE}-\mathrm{HPLC}$ profiles of $\mathrm{EW}_{\mathrm{SD}}, \mathrm{EW}_{\mathrm{SD}} 50^{\circ} \mathrm{C} / 50 \%$ and $\mathrm{EW} \mathrm{SD} 60^{\circ} \mathrm{C} / 80 \%$ in SDS containing medium were mainly dominated by monomeric OVA [peak around 8 min 50 s elution time] (Figure 7.A). The extractability of $\mathrm{EW}_{\mathrm{SD}} 60^{\circ} \mathrm{C} / 80 \%$ in water or SDS medium was about $63 \%$ of that of both $\mathrm{EW}_{\mathrm{SD}}$ and $\mathrm{EW}_{\mathrm{SD}}$ $50^{\circ} \mathrm{C} / 50 \%$ (Figures 7.A and 8.A1), while the major remaining peak of the $\mathrm{EW}_{\mathrm{SD}} 60^{\circ} \mathrm{C} / 80 \%$ sample corresponded to OVA. This shows that ovotransferrin, some other EW proteins and part of OVA became unextractable during the manufacture of $\mathrm{EW}_{\mathrm{SD}} 60^{\circ} \mathrm{C} / 80 \%$ but not during that of $\mathrm{EW}_{\mathrm{SD}} 50^{\circ} \mathrm{C} / 50 \%$. From the above, we conclude that polymers were formed during the dry heating $\mathrm{EW}_{\mathrm{SD}}$ at $60^{\circ} \mathrm{C}$ and $80 \% \mathrm{RH}$ which were no longer extractable in SDS containing medium.

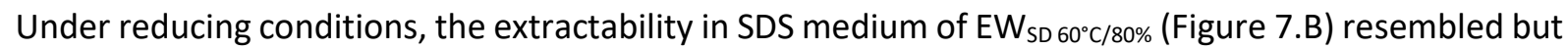

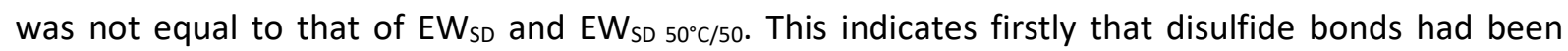
formed in the former sample. Secondly, the SE-HPLC profile of reduced EW $\mathrm{SD}_{60}^{\circ} \mathrm{C} / 80 \%$ still contained some polymers (eluting between $5 \mathrm{~min}$ and $7 \mathrm{~min}$ and $30 \mathrm{~s}$ ), which were less present or not detected in reduced $\mathrm{EW}_{\mathrm{SD}}$ and $\mathrm{EW}_{\mathrm{SD}} 50^{\circ} \mathrm{C} / 50 \%$, indicating the presence of non-disulfide cross-links in $\mathrm{EW}_{\mathrm{SD} 60^{\circ} \mathrm{C} / 80 \%}$. It has been reported that intermolecular cross-links other than disufide bonds can be formed during dry heating of EW powders (Kato, Ibrahim, Watanabe, Honma, \& Kobayashi, 1989; Ma et al., 2019). Under the conditions studied here, dry heating of EW $\mathrm{SD}_{\mathrm{D}}$ had a limited impact on the ThT fluorescence values (Figure 8.B1). Still, TEM images showed some worm-like fibrils (length ca. 80 to $100 \mathrm{~nm}$ ) combined with amorphous aggregates in both $\mathrm{EW}_{\mathrm{SD}} 50^{\circ} \mathrm{C} / 50$ and $\mathrm{EW}_{\mathrm{SD}} 60^{\circ} \mathrm{C} / 80 \%$ (Figure 9). In general, $\mathrm{EW}_{S \mathrm{SD}}$ and $\mathrm{EW}_{\mathrm{SD} 50^{\circ} \mathrm{C} / 50}$ had similar protein characteristics while $\mathrm{EW}_{\mathrm{SD}} 60^{\circ} \mathrm{C} / 80 \%$ contained more insoluble protein aggregates. However, dry heating of EW $\mathrm{SD}$ at the tested conditions $\left(50^{\circ} \mathrm{C}\right.$ and $50 \% \mathrm{RH}$ or $60{ }^{\circ} \mathrm{C}$ and $80 \%$ $\mathrm{RH}$ ) had only a limited impact on protein fibrillation. 

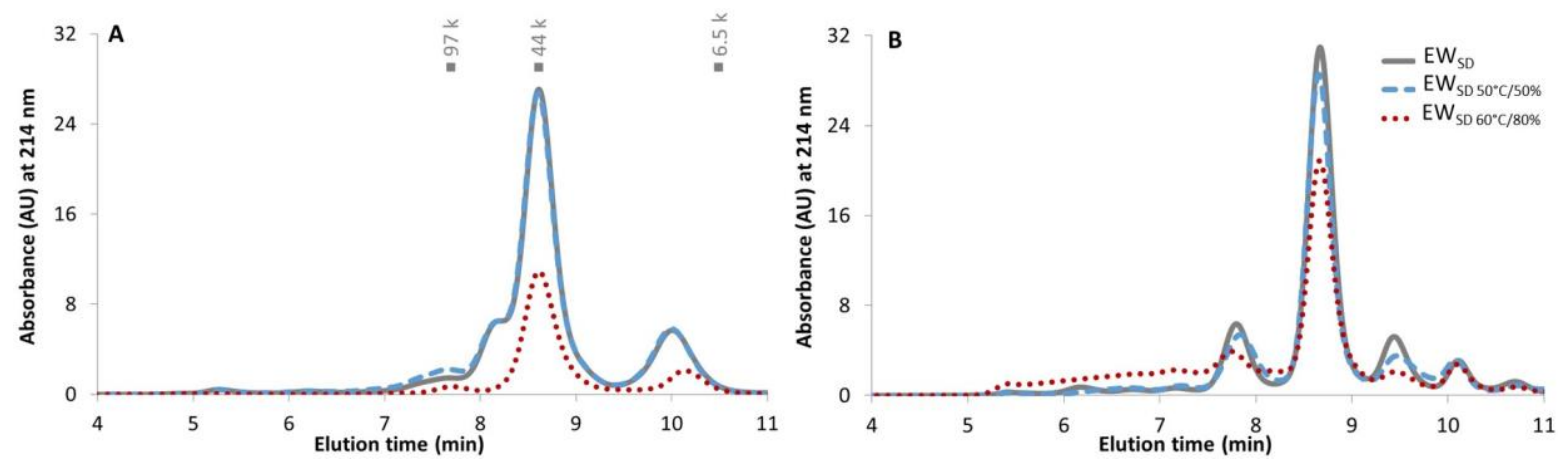

Figure 7. Size exclusion high performance liquid chromatography (SE-HPLC) profiles of spray-dried egg white (EWSD) stored at $50^{\circ} \mathrm{C}$ and $50 \%$ of relative humidity $(R H)\left[E W_{S D} 50^{\circ} \mathrm{C} / 50 \%\right]$ and at $60^{\circ} \mathrm{C}$ and $80 \% R H\left(E W_{S D} 60^{\circ} \mathrm{C} / 80 \%\right)$ both for one week and extracted with sodium dodecyl sulfate (SDS) containing medium (A) or such medium containing $1.0 \%(\mathrm{w} / \mathrm{v})$ dithioethreitol (B). Molecular weights of markers $(6.5,44$ and $97 \mathrm{k})$ are indicated at the top of profile $A$. $A U$, arbitrary units.

Next, dry heated $\mathrm{EW}_{\mathrm{SD}}$ in water was heated under the optimized fibrillation conditions (see section 3.2) and its fibrillation was studied. After heating, the increment in ThT fluorescence was larger for EW $\mathrm{SD}$ $60^{\circ} \mathrm{C} / 80 \%$ than for both $\mathrm{EW}_{S D}$ and $\mathrm{EW}_{\mathrm{SD}} 50^{\circ} \mathrm{C} / 50$. The SE-HPLC profiles of heated $\mathrm{EW}_{S D}, \mathrm{EW}_{S D} 50^{\circ} \mathrm{C} / 50 \%$ and $\mathrm{EW}_{S D}$ $60^{\circ} \mathrm{C} / 80 \%$ revealed the presence of large protein aggregates with a wide protein distribution (elution time ca. 5 to $9 \mathrm{~min}$ ) with increased ThT fluorescence (Figures 8.A2 and 8.B2). As a result of the heating treatment, the largest polymers of $\mathrm{EW}_{\mathrm{SD}} 60^{\circ} \mathrm{C} / 80 \%$ eluting around $5 \mathrm{~min}$ had a larger increment in ThT fluorescence than those of $\mathrm{EW}_{\mathrm{SD}} 50^{\circ} \mathrm{C} / 50 \%$ (Figures 8.A2 and 8.B2). This indicated a higher level of cross$\beta$ sheets in the former.
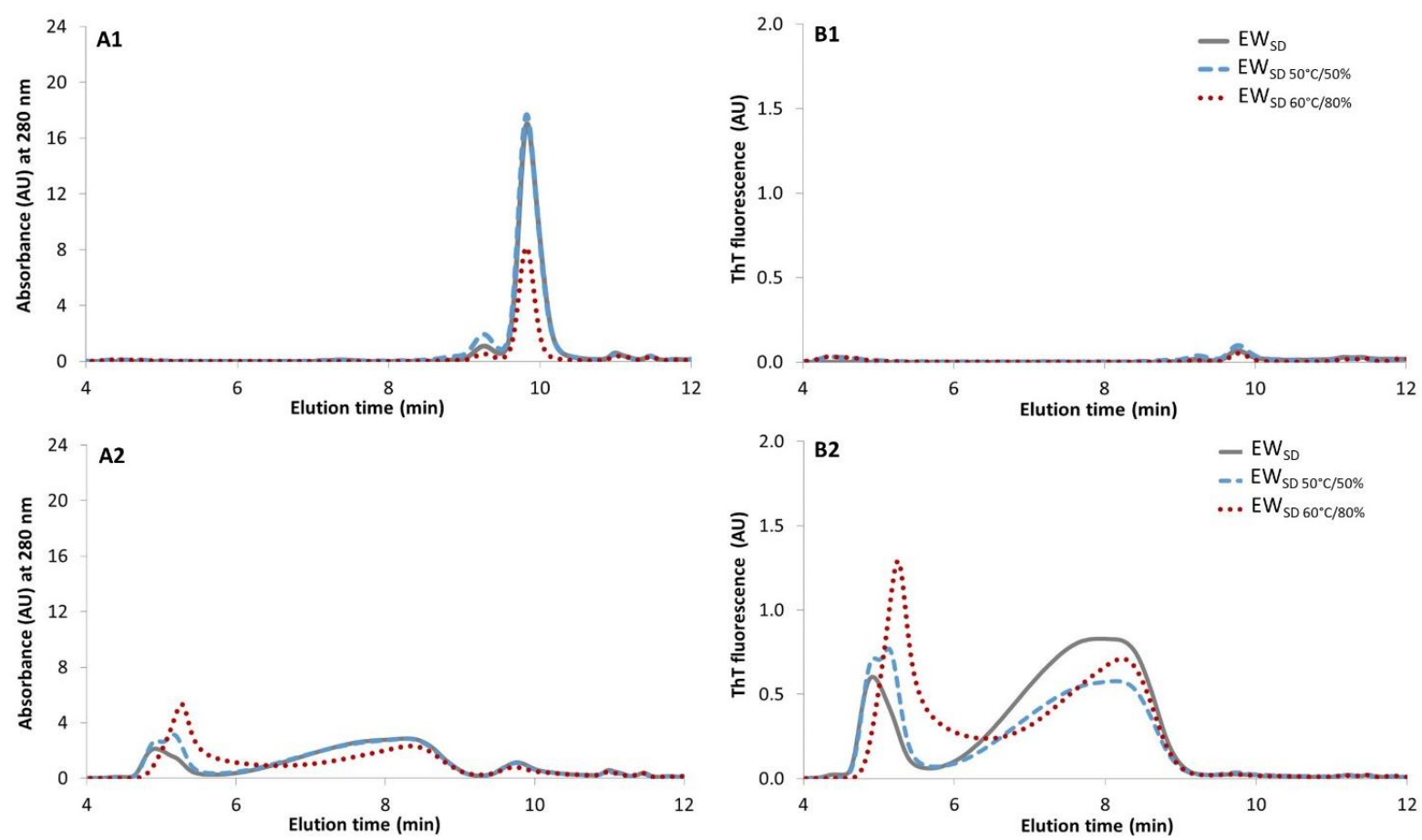

Figure 8. Size exclusion high performance liquid chromatography (SE-HPLC) profiles of unheated (1) spray-dried white $\left(E W_{S D},-\right)$, stored for one week either at $50{ }^{\circ} \mathrm{C}$ and $50 \%$ of relative humidity (RH) [EWSD $50^{\circ} \mathrm{C} / 50 \%,--$ ] or at $60{ }^{\circ} \mathrm{C}$ and $80 \%$ RH $\left(E W_{S D} 60^{\circ} \mathrm{C} / 80 \%, \cdots \bullet\right)$ and then heated (2) under optimal conditions [i.e. $0.5 \%$ ( w protein $\left./ \mathrm{V}\right)$ at $\mathrm{pH} 7.0,85^{\circ} \mathrm{C}$ for $24 \mathrm{~h}$ ]. UV absorbance (A) measured at $280 \mathrm{~nm}$ and thioflavin $T$ (ThT) fluorescence (B) were measured. AU, arbitrary units. 
TEM images of heated EW $\mathrm{SD}$ dispersions showed mainly large amorphous aggregates (length $>200 \mathrm{~nm}$ ) with some small protein fibrils (length ca. 40 to $100 \mathrm{~nm}$ ), while fibrillary structures were observed for

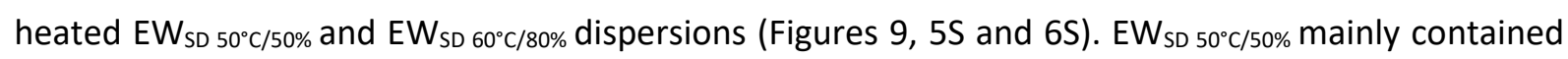
small (length ca. 30 to $130 \mathrm{~nm}$ ) worm-like protein fibrils (Figures 9 and 5S), while large worm-like protein fibrils clusters (length $>200 \mathrm{~nm}$ ) in combination with medium length worm-like protein fibrils (length $c a$. 100 to $200 \mathrm{~nm}$ ) were present in heated EW $\mathrm{SD}_{60}^{\circ} \mathrm{c} / 80 \%$ (Figures 9 and 6S). In addition, comparison of the FTIR spectra of unheated and heated EW SD showed a shift to lower wavenumbers as a result of heating and thus the presence of more ordered secondary protein structures (Figure 3.B). The FTIR spectra of both unheated $\mathrm{EW}_{\mathrm{SD} 50^{\circ} \mathrm{C} / 50 \%}$ and $\mathrm{EW}_{\mathrm{SD}} 60^{\circ} \mathrm{C} / 80 \%$ and their further heated counterparts (data not shown) had the characteristic $\beta$-sheet wavenumbers which evidently suggests that the fibrils they contain are amyloid-like.

In general, dry-heating of $\mathrm{EW}_{\mathrm{SD}}$ at $60{ }^{\circ} \mathrm{C}$ and $80 \% \mathrm{RH}$ enhanced the unfolding, covalent network formation and aggregation of protein. In addition, heating at optimal conditions $\left[0.5 \%\left(\mathrm{w}_{\text {protein }} / \mathrm{v}\right), 22 \mathrm{~h}\right.$ at $85^{\circ} \mathrm{C}$ and $\mathrm{pH} 7.0$ ] enhanced fibrillation. Possibly, the unfolding of ovotransferrin and other proteins during the dry heating can expose aggregation prone regions that promote fibrillation during subsequent heating in excess of water.
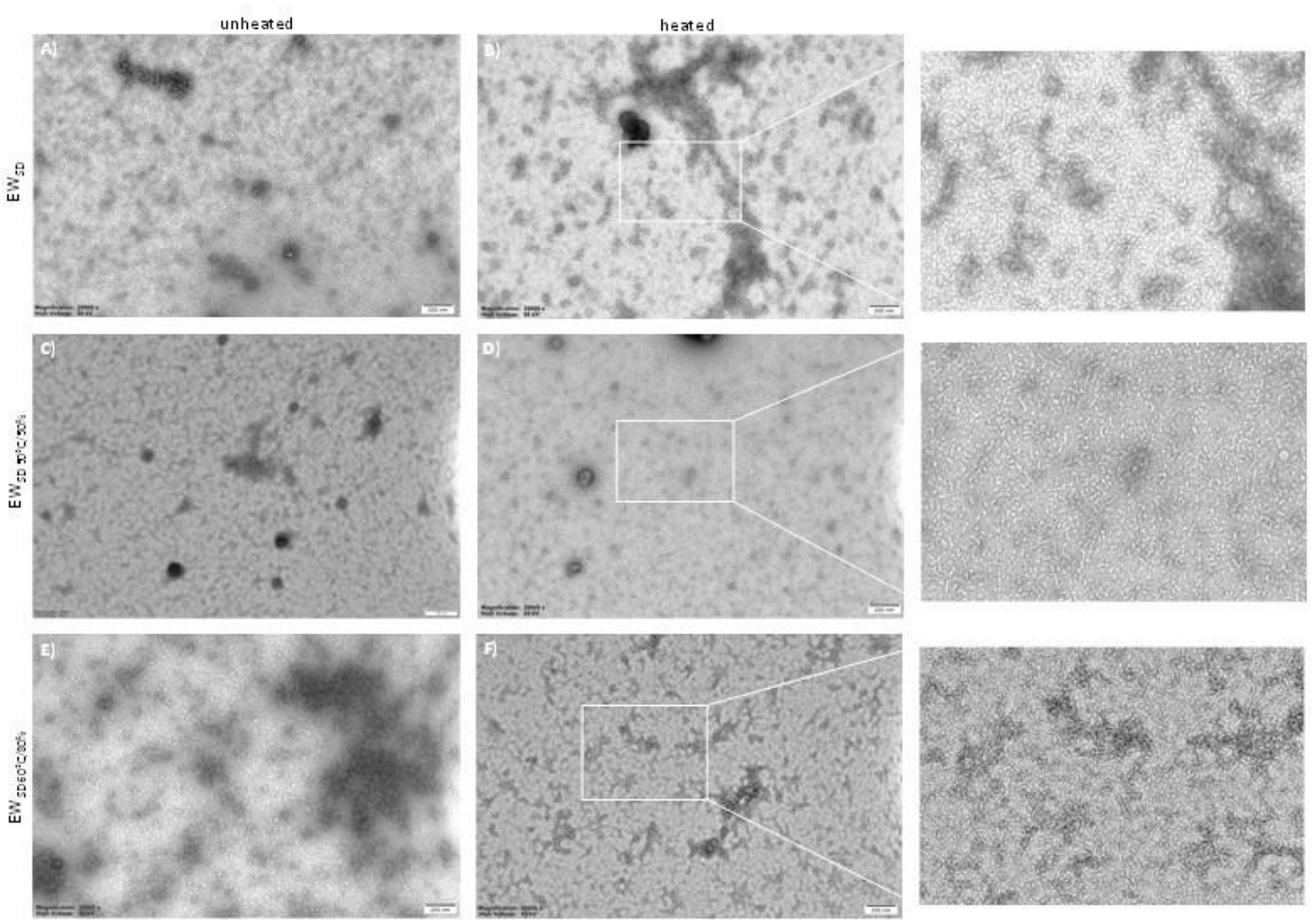

Figure 9. Transmission electron microscopy (TEM) images of unheated ( $A, C$ and $E)$ aqueous proteins solutions/dispersions of spray-dried egg white $\left(E W_{S D}\right)$, stored at $50^{\circ} \mathrm{C}$ and $50 \%$ of relative humidity $(R H)\left[E W_{S D} 50^{\circ} \mathrm{C} / 50 \%\right]$ and at $60{ }^{\circ} \mathrm{C}$ and $80 \% R H\left(E W_{S D}\right.$ $60^{\circ} \mathrm{C} / 80 \%$ ) both for one week as well as further heated ( $B, D$ and $F$ ) at optimal processing conditions [i.e. $0.4 \%\left(W_{\text {protein }} / \mathrm{V}\right)$ at $\mathrm{pH}$ 7.0, $85^{\circ} \mathrm{C}$ for $24 \mathrm{~h}$ ]. Scale bar: $200 \mathrm{~nm}$. 


\section{Conclusions}

Common food manufacturing may induce amyloid fibril formation. This paper showed for the first time that drying EW induces the formation of amyloid-like fibrils and that those obtained by spray-drying (ca. 100 to $200 \mathrm{~nm}$ ) are longer than those by freeze-drying (ca. 20 to $100 \mathrm{~nm}$ ). EW protein fibrillation seems to be dominated by its main protein OVA. In the ranges studied, the optimal temperature for $\mathrm{EW}_{\mathrm{FD}}$ fibrillation is higher $\left(\right.$ e.g. $\left.85^{\circ} \mathrm{C}\right)$ than for $\mathrm{OVA}_{\mathrm{FD}}\left(\right.$ e.g. $\left.76^{\circ} \mathrm{C}\right)$ solely. Both neutral $\mathrm{pH}$ and longer incubation times ( $c a .24 \mathrm{~h}$ ) promote $\mathrm{OVA}_{\mathrm{FD}}$ and EWFD fibrillation. After heating at optimal conditions, $\mathrm{OVA}_{\mathrm{FD}}$ contains worm-like fibrils which are longer ( $c a .60$ to $150 \mathrm{~nm}$ ) than those formed in $\mathrm{EW}_{\mathrm{FD}}(\mathrm{ca} .50$ $\mathrm{nm}$ ). Fibril formation can be stimulated by some dry-heating conditions. Dry heating of EWSD at $50{ }^{\circ} \mathrm{C}$ and $50 \%$ RH for one week had limited impact on protein aggregation and fibril formation. More severe conditions ( $60{ }^{\circ} \mathrm{C}, 80 \% \mathrm{RH}$, one week) promoted the formation of insoluble protein aggregates (stabilized by both disulfide and non-disulfide cross-links), but without formation of protein fibrils. However, as a result of heating $\mathrm{EW}_{S \mathrm{SD}} 60^{\circ} \mathrm{C} / 80 \%$ in excess of water larger protein fibrils (ca. 100 to $200 \mathrm{~nm}$ ) were observed than for $\mathrm{EW}_{\mathrm{SD}} 50^{\circ} \mathrm{C} / 50 \%$ ( $c a .30$ to $130 \mathrm{~nm}$ ) heated under similar conditions. The presence of protein fibrils in dried EW products underlines the potential relevance of AFs in food products. The impact of such fibrils on the techno-functional properties of dried EW should therefore be further investigated. In addition, it would seem useful to gain insight in the proteolytic resistance in the intestinal human tract of these protein structures. Finally, it is possible that specific techno-functional properties of EW proteins can be tailored by promoting the formation AFs in dried EW products.

\section{Acknowledgments}

The Research Foundation-Flanders (FWO) is thanked for SBO grant S003918N and postdoctoral mandate grant $12 \mathrm{~V} 6718 \mathrm{~N}$ of M.A. Lambrecht. The Switch Laboratory was supported by ERC Grant 647458 (MANGO) to J. Schymkowitz, the Flanders Institute for Biotechnology (VIB), the KU Leuven, the FWO-Flanders, IWT (SBO grant 60839) and Belspo (IUAP grant P7/16). R. Matthys is thanked for excellent technical assistance. The Electron Platform \& Bio Imaging Core (KU Leuven, VIB) is gratefully thanked for assistance with TEM analysis. M. Monge-Morera thanks the University of Costa Rica for permission to perform research abroad. J.A. Delcour is W. K. Kellogg Chair in Cereal Science and Nutrition at the KU Leuven and beneficiary of Methusalem excellence funding at the KU Leuven.

\section{References}

Baron, F., Nau, F., Guérin-Dubiard, C., Gonnet, F., Dubois, J. J., \& Gautier, M. (2003). Effect of dry heating on the microbiological quality, functional properties, and natural bacteriostatic ability of egg white after reconstitution. Journal of Food Protection, 66(5), 825-832. 
455

456

457

458

459

460

461

462

463

464

465

466

467

468

469

470

471

472

473

474

475

476

477

478

479

480

481

482

483

Chen, C., Chi, Y. J., \& Xu, W. (2012). Comparisons on the functional properties and antioxidant activity of spray-dried and freeze-dried egg white protein hydrolysate. Food and Bioprocess Technology, 5(6), 2342-2352. https://doi.org/10.1007/s11947-011-0606-7

Donovan, J. W., Mapes, C. J., Gorton Davis, J., \& Garibaldi, J. A. (1975). A diferential scanning calorimetric study of the stability of egg white to heat denaturation. Journal of the Science of Food and Agriculture, 26(1), 73-83.

Eisele, Y. S., Monteiro, C., Fearns, C., Encalada, S. E., Wiseman, R. L., Powers, E. T., \& Kelly, J. W. (2015). Targeting protein aggregation for the treatment of degenerative diseases. Nature Reviews Drug Discovery, 14(11), 759-780. https://doi.org/10.1038/nrd4593

Goos, P., \& Jones, B. (2011). Optimal design of experiments: a case study approach (1st ed.). West Sussex: Wiley.

Haque, M. K., \& Roos, Y. H. (2006). Differences in the physical state and thermal behavior of spraydried and freeze-dried lactose and lactose/protein mixtures. Innovative Food Science and Emerging Technologies, 7(1-2), 62-73. https://doi.org/10.1016/j.ifset.2004.12.004

Jansens, K. J. A., Lambrecht, M. A., Rombouts, I., Monge Morera, M., Brijs, K., Rousseau, F., Schymkowitz, J., \& Delcour, J. A. (2019). Conditions governing food protein amyloid fibril formation-part I: egg and cereal proteins. Comprehensive Reviews in Food Science and Food Safety, 18, 1256-1276. https://doi.org/10.1111/1541-4337.12462

Jansens, K. J. A., Rombouts, I., Grootaert, C., Brijs, K., Van Camp, J., Van der Meeren, P., Rousseau, F., Schymkowitz, J., \& Delcour, J. A. (2019). Rational design of amyloid-like fibrillary structures for tailoring food protein techno-functionality and their potential health implications. Comprehensive Reviews in Food Science and Food Safety, 18, 84-105. https://doi.org/10.1111/1541-4337.12404

Jin, Y., Zeng, Q., Geng, F., \& Ma, M. (2020). Characterization of the interaction between hen egg white lysozyme and ovalbumin: Interaction between lysozyme and ovalbumin. Food Bioscience, 36(June), 100674. https://doi.org/10.1016/j.fbio.2020.100674

Kato, A., Ibrahim, H. R., Watanabe, H., Honma, K., \& Kobayashi, K. (1989). New approach to improve the gelling and surface functional properties of dried egg white by heating in dry state. Journal of Agricultural and Food Chemistry, 37(2), 433-437. https://doi.org/10.1021/jf00086a036 
Kong, J., \& Yu, S. (2007). Fourier transform infrared spectroscopic analysis of protein secondary structures. Acta Biochimica et Biophysica Sinica, 39(8), 549-559. https://doi.org/10.1111/j.17457270.2007.00320.x

Lambrecht, M. A., Jansens, K. J. A., Rombouts, I., Brijs, K., Rousseau, F., Schymkowitz, J., \& Delcour, J. A. (2019). Conditions governing food protein amyloid fibril formation-part II: milk and legume proteins. Comprehensive Reviews in Food Science and Food Safety, 18, 1277-1291. https://doi.org/10.1111/1541-4337.12462

Lambrecht, M. A., Rombouts, I., De Ketelaere, B., \& Delcour, J. A. (2017). Prediction of heat-induced polymerization of different globular food proteins in mixtures with wheat gluten. Food Chemistry, 221, 1158-1167. https://doi.org/10.1016/j.foodchem.2016.11.043

Lechevalier, V., Jeantet, R., Arhaliass, A., Legrand, J., \& Nau, F. (2007). Egg white drying: influence of industrial processing steps on protein structure and functionalities. Journal of Food Engineering, 83(3), 404-413. https://doi.org/10.1016/j.jfoodeng.2007.03.033

Liapis, A. I., \& Bruttini, R. (2007). Freeze drying. In A. S. Mujumdar (Ed.), Handbook of Industrial Drying (3rd ed., pp. 257-284). Boca Raton: CRC Press.

Lili, L., Huan, W., Guang Yue, R., Xu, D., Dan, L., \& Guang Jun, Y. (2015). Effect of freeze-drying and spray drying processes on functional properties of phosphorylation of egg white protein. International Journal of Agricultural and Biological Engineering, 8(4), 116-123. https://doi.org/10.3965/j.ijabe.20150804.1942

Ma, S., Zhao, S., Zhang, Y., Yu, Y., Liu, J., \& Xu, M. (2013). Quality characteristic of spray-drying egg white powders. Molecular Biology Reports, 40(10), 5677-5683. https://doi.org/10.1007/s11033013-2669-1

Ma, Y., Zhao, Y., \& Chi, Y. (2019). Changes in the gel characteristics of two hen egg white powders modified by dry heating and the Maillard reaction during long-term storage. Lwt, 109(April), 123129. https://doi.org/10.1016/j.Iwt.2019.04.003

Ma, Y., Zhao, Y., Jiang, Y., \& Chi, Y. (2019). Effect of dry heating on the aggregation behaviour and aggregate morphologies of ovalbumin. Food Chemistry, 285, 296-304. https://doi.org/10.1016/j.foodchem.2019.01.170

Mariño, L., Maya-Aguirre, C. A., Pauwels, K., Vilanova, B., Ortega-Castro, J., Frau, J., Donoso, J., \& Adrover, M. (2017). Glycation of lysozyme by glycolaldehyde provides new mechanistic insights 
in diabetes-related protein aggregation. ACS Chemical Biology, 12(4), 1152-1162. https://doi.org/10.1021/acschembio.6b01103

Maurer-Stroh, S., Debulpaep, M., Kuemmerer, N., Lopez de la Paz, M., Martins, I. C., Reumers, J., Morris, K. L., Copland, A., Serpell, L. C., Serrano, L., Schymkowitz, J. W. H., \& Rousseau, F. (2010). Exploring the sequence determinants of amyloid structure using position-specific scoring matrices. Nature Methods, 7(3), 237-242. https://doi.org/10.1038/nmeth.1432

Mine, Y. (1995). Recent advances in the understanding of egg white protein functionality. Trends in Food Science \& Technology, 6, 225-232. https://doi.org/https://doi.org/10.1016/S09242244(00)89083-4

Mine, Y. (1996). Effect of pH during the dry heating on the gelling properties of egg white proteins. Food Research International, 29(2), 155-161. https://doi.org/10.1016/0963-9969(96)00008-7

Mine, Y. (1997). Effect of dry heat and mild alkaline treatment on functional properties of egg white proteins. Journal of Agricultural and Food Chemistry, 45(8), 2924-2928. https://doi.org/10.1021/jf970158b

Mine, Y. (2002). Recent advances in egg protein functionality in the food system. World's Poultry Science Journal, 58, 31-39. https://doi.org/10.1079/WPS20020005

Monge-Morera, M., Lambrecht, M. A., Deleu, L. J., Gallardo, R., Louros, N. N., De Vleeschouwer, M., Rousseau, F., Schymkowitz, J., \& Delcour, J. A. (2020). Processing induced changes in food proteins: amyloid formation during boiling of hen egg white. Biomacromolecules, 21, 2218-2228. https://doi.org/10.1021/acs.biomac.0c00186

Pearce, F. G., Mackintosh, S. H., \& Gerrard, J. A. (2007). Formation of amyloid-like fibrils by ovalbumin and related proteins under conditions relevant to food processing. Journal of Agricultural and Food Chemistry, 55, 318-322. https://doi.org/10.1021/jf062154p

Photchanachai, S., Mehta, A., \& Kitabatake, N. (2002). Heating of an ovalbumin solution at neutral pH and high temperature. Bioscience, Biotechnology and Biochemistry, 66(8), 1635-1640. https://doi.org/10.1271/bbb.66.1635

Powrie, W. D., \& Nakai, S. (1985). Characteristics of edible fluids of animal origin: eggs. In O. R. Fennema (Ed.), Food Chemistry (2nd ed., pp. 829-855). New York: Marcel Dekker.

Rousseau, F., Schymkowitz, J., \& Serrano, L. (2006). Protein aggregation and amyloidosis: confusion of the kinds? Current Opinion in Structural Biology, 16, 118-126. 
545

546

547

548

549

550

551

552

553

554

555

556

557

558

559

560

561

562

563

564

565

566

567

568

569

570

571

572

573

Sosnik, A., \& Seremeta, K. P. (2015). Historical perspective. Advantages and challenges of the spraydrying technology for the production of pure drug particles and drug-loaded polymeric carriers. Advances in Colloid and Interface Science, 223, 40-54. https://doi.org/10.1016/j.cis.2015.05.003

Sugimoto, Y., Kamada, Y., Tokunaga, Y., Shinohara, H., Matsumoto, M., Kusakabe, T., Ohkuri, T., \& Ueda, T. (2011). Aggregates with lysozyme and ovalbumin show features of amyloid-like fibrils. Biochemical and Cell Biology, 59, 533-544.

Sunde, M., Serpell, L. C., Bartlam, M., Fraser, P. E., Pepys, M. B., \& Blake, C. C. F. (1997). Common core structure of amyloid fbrils by synchrotron X-ray diffraction. The Journal of Molecular Biology, 273, 729-739. https://doi.org/10.1006/jmbi.1997.1348

Tanaka, N., Morimoto, Y., Noguchi, Y., Tada, T., Waku, T., Kunugi, S., Morii, T., Lee, Y. F., Konno, T., \& Takahashi, N. (2011). The mechanism of fibril formation of a non-inhibitory serpin ovalbumin revealed by the identification of amyloidogenic core regions. Journal of Biological Chemistry, 286, 5884-5894. https://doi.org/10.1074/jbc.M110.176396

Tani, F., Shirai, N., Onishi, T., Venelle, F., Yasumoto, K., \& Doi, E. (1997). Temperature control for kinetic refolding of heat-denatured ovalbumin. Protein Science, 6, 1491-1502. https://doi.org/10.1002/pro.5560060713

Vassar, P. S., \& Culling, C. F. (1959). Fluorescent stains, with special reference to amyloid and connective tissues. Archives of Pathology, 68, 487-498.

Weijers, van de Velde, F., Stijnman, A., van de Pijpekamp, A., \& Visschers, R. W. (2006). Structure and rheological properties of acid-induced egg white protein gels. Food Hydrocolloids, 20, 146-159. https://doi.org/10.1016/j.foodhyd.2005.02.013

Zandomeneghi, G., Krebs, M. R. H., McCammon, M. G., \& Fändrich, M. (2009). FTIR reveals structural differences between native $\beta$-sheet proteins and amyloid fibrils. Protein Science, 13(12), 33143321. https://doi.org/10.1110/ps.041024904

Zhang, Q., Ames, J. M., Smith, R. D., Baynes, J. W., \& Metz, T. O. (2009). A Perspective on the Maillard Reaction and the Analysis of Protein Glycation by Mass Spectrometry: Probing the Pathogenesis of Chronic Disease. Journal of Proteome Research, 8(2), 754-769. https://doi.org/10.1021/pr800858h

Zhang, Y., Liang, S., Zhang, J., Chi, Y., Tian, B., Li, L., Jiang, B., Li, D., Feng, Z., \& Liu, C. (2020). Preparation 
574 of whey protein isolate nanofibrils by microwave heating and its application as carriers of

575 lipophilic bioactive substances. LWT - Food Science and Technology, 125, 109213.

$576 \quad$ https://doi.org/10.1016/j.Iwt.2020.109213

577 